\title{
The Anthropocene, Five Discourses and Frontier Space
}

\author{
Ellen Hey
}

In just under two decades, the idea that we are living in the Anthropocene, the epoch in which humans are affecting the Earth system, has prompted a wealth of academic publications in a variety of disciplines. Despite calls for collaboration, ${ }^{2}$ several discourses with diverging epistemologies seem to be contending to shape our understanding of the Anthropocene. Does this point to the existence of a conceptual frontier space?

'Frontier' conventionally refers to a space, material or conceptual, populated by pioneers in which there is room for experimentation, plurality and opportunity at the periphery; a space beyond control of the centre. ${ }^{3}$ Yet, frontier space in its material sense may have been more closely interlinked with the centre than generally assumed because frontier activities often depended on the centre for, among other things, investments and consumers. ${ }^{4}$ Moreover, exploring frontier space in the material sense more often than not involved marginalization of individuals and groups. ${ }^{5}$ It also has been suggested that in

1 I am indebted to Alessandra Arcuri, Louis Kotzé, Marijn van der Sluis and the editors of this volume for valuable comments on draft versions of this chapter. The usual disclaimer applies. All websites included in this essay were accessed on 1 May 2020.

2 See, e.g., ES Brondizio, K O’Brien, X Bai et al., 'Re-conceptualizing the Anthropocene: A Call for Collaboration' (2016) 39 Global Environmental Change 318-327.

3 FJ Turner, 'The Significance of the Frontier in American History' in FJ Turner (ed), The Frontier in American History (Henry Hold \& Co., 1921) 1-36, http://www.gutenberg.org/files/ 22994/22994-h/22994-h.htm. For an overview of the (critical) reception Turner's frontier thesis has received see E Altenbernd and AT Young, 'Introduction: The Significance of the Frontier in an Age of Transnational History' (2014) 492 Settler Colonial Studies 127-150. See further Barnes and Long, chapter 1 of this volume.

4 W Cronon, 'The Kenecott Journey, the Paths out of Town' in W Cronon, G Miles and J Gitlin (eds), Under An Open Sky, Rethinking America's Past (WW Norton \& Company, 1992) 28-51, $276-281$.

5 See, e.g., E Galeano, Las venas abiertas de América Latina (4th ed, Siglo xxi Editores, 1986). For a novel that explores American frontier society in all its multifacets and which 
order to develop emancipatory epistemologies more than 'frontier thinking' in the conventional sense, as outlined above, is required. ${ }^{6}$ These various layers of the notion of frontier point to the relevance of connections in frontier space as well as the political implications of what might be taking place in frontier space and thus suggest that frontier space is multifaceted. The notion of frontier as summarized above foregrounds four questions. First, where might the centre and periphery be located in the conceptual space in which Anthropocene related discourses take place? Second, to what extent do plurality, experimentation and opportunity figure in this space? Third, where might marginalization occur? Fourth, what types of thinking are ongoing in the conceptual space in which Anthropocene related discourses take place?

This chapter first examines the challenges that the idea of the Anthropocene poses in terms of existing and new juxtapositions or, to stay within the theme of this volume, 'boundaries'. It then proceeds to characterize Anthropocene related discourses. Thereafter it engages in an attempt to depict the conceptual space in which Anthropocene related discourses take place, using the notion of frontier as outlined above as heuristic guidance.

\section{$2 \quad$ Boundaries and the Anthropocene}

The idea of the Anthropocene suggests the emergence of new and reemergence of existing boundaries. These boundaries may be material or conceptual and they are intertwined. Importantly, some of these boundaries raise political challenges. ${ }^{7}$

Materially, the idea of the Anthropocene denotes the move, from the Holocene, into a new geological epoch: the Anthropocene. Identifying the beginning of the Anthropocene involves significant conceptual challenges. ${ }^{8}$ It requires collecting and interpreting the evidence to substantiate the claim that

I happened to be reading while working on this essay, see Annie Proulx, Barkskins (Harper Collins Publisher, 2016).

6 B de Sousa Santos, 'Three Metaphors for a New Conception of Law: The Frontier, the Baroque, and the South' (1995) 29(4) Law and Society Review 569-584. See text at notes -. See also S Adelman, 'Epistemologies of Mastery' and A Philippopoulos-Mihalopoulos, 'Epistemologies of Doubt' both in A Gear and LJ Kotzé (eds), Research Handbook on Human Rights and the Environment (Edward Elgar, 2015) 9-27 and 28-45.

7 See for example, Scovazzi, Chapter 8, the present volume.

8 CN Waters, J Zalasiewicz, C Summerhayes et al., 'Global Boundary Stratotype Section and Point (GSSP) for the Anthropocene Series: Where and How to Look for Potential Candidates' (2018) 178 Earth Science Reviews 379-429. 
the human imprint is discernible in geological strata and situating the boundary between the Holocene and the Anthropocene. In 2016, the Anthropocene Working Group provisionally recommended that we are living in the Anthropocene and proposed that the border with the Holocene be situated at a point in the mid-twenieth century, with the exact date and geological marker still to be determined. ${ }^{9}$ The Working Group identified two possible candidates for designating the boundary between the Holocene and Anthropocene. These are the worldwide traceability in geological deposits of nuclear testing, peaking around 1964, and of materials associated with 'accelerated technological development, rapid growth of the human population, and the increased consumption of resources', evident from around $1950 .^{10}$ The latter developments, also known as the Great Acceleration, were accompanied by a steep increase in worldwide economic activity. ${ }^{11}$ Regardless which of the two markers is chosen to determine the boundary between the Holocene and the Anthropocene, the political implication is that institutions and practices originating in the North are implied in the advent of the Anthropocene. As argued elsewhere, these political implications have antecedents traceable to at least the colonial era and can be mapped onto international law. ${ }^{12}$ These antecedents and their current manifestations raise challenges in the context of the divide between the global South and global North. Materially, the idea of the Anthropocene then suggests a new boundary, in the sense of a border, between the Holocene and the Anthropocene, as well as the re-emergence into prominence of an existing political boundary, the divide between the global South and global North.

Conceptually, the idea of the Anthropocene points to the merging of what we thought to be natural and what we thought to be human. It suggests a redefinition of our past, ontologically and epistemologically, but also our present and future. Instead of divided, the social and natural are to be understood as intimately intertwined, with humans being a force of change affecting the Earth system. As a result, the idea that the natural sciences deal with nature

9 CN Waters, J Zalasiewicz, C Summerhayes et al., 'The Anthropocene is Functionally and Stratigraphically Distinct from the Holocene' (2016) 351(6269) Nature (aad2622-I) 137-344; see also, University of Leicester, 'Media note: Anthropocene Working Group (AWG)' 29 August 2016, http://www2.le.ac.uk/offices/press/press-releases/2016/august/media-noteanthropocene-working-group-awg. For information about the Anthropocene Working Group see text below (n 16-18).

10 Waters et al. (2016), above (n 9), 139 .

11 W Steffen, J Grinevald, P Crutzen and J McNeill, 'The Anthropocene: Conceptual and Historical Perspectives' (2011) 369 Philosophical Transactions of the Royal Society 842-867.

12 E Hey, 'International Law and the Anthropocene' (2016) 5(10) ESIL Reflection, https://esilsedi.eu/esil-reflection-international-law-and-the-anthropocene-2/. 
and relationships in nature and the social sciences and humanities with society and relationships in society becomes contested. These findings have consequences for how we (re)think the boundary between the natural and the social sciences, and the role of human mediation in those sciences. ${ }^{13}$ Such a (re)thinking has political implications for researchers and how we view our disciplines. It also has implications for the policy choices we make. This (re) thinking, I suggest, implicitly plays an important role in Anthropocene related discourses. Conceptually, the advent of the Anthropocene then suggests the disappearance of a boundary, between nature and humans and the need to (re)think the boundary between the natural and social sciences.

In discourses about the Anthropocene these four boundaries - Holocene/ Anthropocene, South/North, nature/humans, natural sciences/social sciences - play a role, even if not always explicitly. This chapter does not explore these boundaries as such, but rather the conceptual space in which Anthropocene related discourses take place and explores the boundaries between these discourses.

Five Discourses on the Anthropocene

Based on academic publications and with the certainty of over-simplifying, I distinguish five discourses in the short history of the idea of the Anthropocene. First, the stratigraphic discourse, associated with geology and stratigraphy in particular. Second, the earth system science discourse, associated with in particular the natural sciences. Third, the earth system governance discourse, associated with the social sciences and political science in particular. Fourth, critical discourse, based mainly in the critical social sciences and humanities. Fifth, legal discourse, engaged in mainly by those with a background in international law. The above is not to suggest that individuals with other disciplinary backgrounds might not be associated with each of these discourses. To name an example, individuals with a background in international law are involved in all five discourses. ${ }^{14}$

13 See, e.g., B Latour, 'War and Peace in an Age of Ecological Conflict' (2014) 1 Revue Juridique

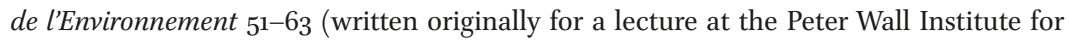
Advanced Studies, Vancouver, 23 September, 2013), http://www.bruno-latour.fr/node/527.

14 Note for example that Davor Vidas is a member of the Anthropocene Working Group and regularly co-publishes with other members of the group, including geologists, as well as with researchers involved in earth system science discourse, see references below (e.g., $\mathrm{n}$ 17 and 20). See also, e.g., Ebbesson (Brill 2014) below (n 44), and A Grear, “Anthopocene, Capitalocene, Chthulucene": Re-encountering Environmental Law and its "Subject" with 
The stratigraphic discourse focuses on the question of whether human impact can be measured in the Earth's geological strata and, if so, what constitutes a proper geological marker and date for the beginning of the Anthropocene. ${ }^{15}$ It takes place under the auspices of the Anthropocene Working Group of the Subcommission on Quaternary Stratigraphy of the International Commission on Stratigraphy of the International Union of Geological Sciences (IUGS). It manifests itself mainly in the publications of its members. ${ }^{16}$ The findings of the working group will have to meet the standards for declaring a new geological unit, in this case an epoch. Whether the findings of the working group meet these standards is the subject of debate. ${ }^{17}$ If the working group comes to a conclusive recommendation about the advent of the Anthropocene as evidenced in geological strata, that recommendation will be subject to a decision-making process consecutively involving three additional bodies that are part of the IUGs. ${ }^{18}$ As a result, a conclusive decision on the advent of the Anthropocene is not to be expected soon.

Paul Crutzen first raised the idea of the Anthropocene in the context of the earth system science network at a meeting of the then International Geosphere-Biosphere Programme (IGBP) in 2000.19 Earth system science focuses on understanding and modelling the Earth system in a holistic way. It involves a variety of disciplines, mainly in the natural sciences, and contributes the perception of the Earth as a single, complex and dynamic system including subsystems, such as the climate system, and complex

Haraway and New Materialism' in LJ Kotzé (ed), Environmental Law and Governance for the Anthropocene (Hart, 2017) 77-96.

15 Waters et al., above (n 8).

16 For the website of the Anthropocene Working Group, see http://quaternary.stratigraphy. org/working-groups/anthropocene/.

17 For an overview of critiques and responses thereto by members of the Anthropocene Working Group (all but one author are members of the Working Group, even if not all members of the Working Group, as listed on its website, authored the publication) see J Zalasiewicz, CN Waters, AP Wolfe et al., 'Making the Case for a Formal Anthropocene Epoch: An Analysis of Ongoing Critiques' (2017) 50(2) Newsletters on Stratigraphy 205-226.

18 Ibid 221.

19 Crutzen received the Nobel Prize in chemistry for his work on the ozone layer. For a popularized account of Crutzen's life and the how the term 'Anthropocene' entered our vocabulary, see 'Prologue: Writing in the Sky' in C Schwägerl, The Anthropocene, the Human Era and How it Shapes our Planet (Synergetic Press, 2014). See also PJ Crutzen and EF Stoermer, “The "Anthropocene" ' (2000) 41 The Global Change Newsletter 17-18; PJ Crutzen, 'The Geology of Mankind' (2002) 415 Nature 23. 
relations of interdependence between its constituents. ${ }^{20}$ One of the outcomes of earth system science research is the identification of quantifiable planetary boundaries, tipping points and a safe operating space for humanity within these boundaries, thereby providing the opportunity for 'avoiding major human-induced environmental change on a global scale. ${ }^{21}$ Planetary boundaries research is linked with social-ecological resilience research. The latter understands social-ecological systems as complex adaptive systems. It focuses on understanding their dynamics in order to achieve more resilient and sustainable social-ecological systems, which manifest themselves at all levels, from local to global scales. ${ }^{22}$ Earth system science was able to develop not least because of the availability of significant resources that it could draw upon as part of the IGBP, which was part of the Earth System Science Partnership (ESSP). ${ }^{23}$ In 2015, the ESSP was replaced by Future Earth of which earth system science is a part. ${ }^{24}$ 'Future Earth is conceived as a 10year programme that builds upon Earth system science and brings together global environmental change researchers to further develop interdisciplinary collaborations that address critical questions'. ${ }^{25}$ It seeks to attain its aims by bringing together disciplines and knowledge fields as well as through collaboration between the scientific community and stakeholders. ${ }^{26}$

Earth system governance research, as its name suggests, is linked to earth system science. Between 2009 and 2015, it was a programme of the International Human Dimensions Programme on Global Environmental Change (IHDP), which was part of the ESSP, and since 2015 it is part of

20 For a summary of the origins and development of earth system science, as well as stratigraphic science, see W Steffen, R Leinfelder, J Zalasiewicz et al., 'Stratigraphic and Earth System Approaches to Defining the Anthropocene' (2016) 4(8) Earth's Future 324-345. See also, W Steffen, RA Sanderson, PD Tyson et al., Global Change and the Earth System (Springer, 2004).

21 J Rockström, W Steffen, K Noone et al., 'Planetary Boundaries: Exploring the Safe Operating Space for Humanity' (2009) 14(2) Ecology and Society 1-32, 1.

22 C Folke, R Biggs, AV Norström et al., 'Social-ecological Resilience and Biosphere-based Sustainability Science' (2016) 21(3) Ecology and Society 41. See also Stockholm Resilience Centre website, https://www.stockholmresilience.org/.

23 E Lövbrand, J Stripple and B Wiman, 'Earth System Governability, Reflections on Science in the Anthropocene' (2009) 19 Global Environmental Change 7-13; HJ Schellnhuber, “'Earth System” Analysis and the Second Copernican Revolution' (1999) 402(Supp) Nature 19-23.

24 See Future Earth website, http://www.futureearth.org/.

25 Future Earth, Future Earth Initial Design: Report of the Transition Team (International Council for Science, 2013) 19; see also, Future Earth, 'Our History', http://www.futureearth. org/history. Ibid 9. 
Future Earth. ${ }^{27}$ In 2007, Frank Biermann, the then chairperson of the Scientific Steering Committee of the Earth System Governance Project, suggested that meaningful engagement of the social sciences with earth system science required a change of conceptual focus from 'management' to 'governance. ${ }^{28}$ Biermann presented the concept of earth system governance as 'a new social phenomenon, a political programme and a crosscutting theme of research in the field of global environmental change'. ${ }^{29} \mathrm{He}$ also presented a broad understanding of what earth system governance involves. It includes, for example, governance at all levels - from local to global - and both public and private spheres, as well as issues of accountability and allocation. Biermann referred to this collectively as 'a global architecture' and 'part of a new democratic governance beyond the nation state'. ${ }^{30}$ The early outcomes of the project indeed focussed on improving the global institutional architecture and how it might attain greater legitimacy and efficacy. Policy recommendations included the following: upgrading the United Nations Environmental Programme (UNEP) to a UN specialized agency; establishing a UN body on sustainable development in which the Group of 20 would have 50 percent of the vote in order to enhance the effectiveness of the body; developing framework conventions for new technologies, such as nanotechnology and geoengineering; mainstreaming environmental goals into global economic law; introducing majority or weighted voting; and further development of novel financial mechanisms that facilitate the transfer of funds from developed to developing States. ${ }^{31}$ Earth system governance research engages with stratigraphic and Earth system science discourses $^{32}$ and has reported research that contextualizes the Anthropocene by focussing on various levels of governance and their linkages. ${ }^{33}$ Earth

27 See Future Earth, 'ESG: Earth System Governance', http://www.futureearth.org/projects/ esg-earth-system-governance.

28 F Biermann, "Earth System Governance” as a Crosscutting Theme of Global Change Research' (2007) 17 Global Environmental Change 326-337.

29 Ibid 327.

$30 \quad$ Ibid 335 .

31 F Biermann, K Abbott, S Andresen et al., 'Navigating the Anthropocene: Improving Earth System Governance' (2012) 335(6o74) Science 1306-1307.

32 F Biermann, 'Planetary Boundaries and Earth System Governance: Exploring the Links' (2012) 81 Ecological Economics 4-9; V Galaz, F Biermann, B Crona et al., "'Planetary Boundaries"-Exploring the Challenges for Global Environmental Governance' (2012) 4 Current Opinion in Environmental Sustainability 1-8; F Biermann, 'The Anthropocene: A Governance Perspective' (2014) 1(1) The Anthropocene Review 57-61.

33 F Biermann, X Bai, N Bondre et al., 'Down to Earth: Contextualizing the Anthropocene' (2016) 39 Global Environmental Change 341-350. 
system governance discourse also engages with the divide between the global South and global North. ${ }^{34}$

Critical discourse addresses the topic of the Anthropocene from many different disciplinary perspectives available in the social sciences and humanities $^{35}$ as well as law. ${ }^{36}$ Several themes reoccur in critical discourse. First, illustration of how dominant paradigms associated with neo-colonialism, neoliberalism, capitalism and consumerism are entrenched in our institutions, historically and extant. Second, how de-politicization and objectivation strategies, which suggest that environmental problems can be addressed by knowledge about the environment and technological developments, downgrade the importance of social, cultural and political considerations in addressing the Anthropocene. Third, highlighting issues of fairness and justice linked to, for example, the question 'who amongst humanity is responsible for environmental degradation?' The latter theme raises challenges in the context of relations between the global South and global North. ${ }^{37}$ For example, should an Egyptian subsistence farmer, a Venezuelan slum dweller, an Australian aborigine or an unemployed, slum dwelling single parent living in the North be equally as responsible for climate change as a Dutch law professor, who frequently drives her car to work and travels by plane? Critical discourse also includes critiques of stratigraphic and earth system science discourses, including Future Earth, for being too focussed on the natural sciences and solution oriented environmental research as ways of addressing Anthropocene exigencies. ${ }^{38}$ It furthermore includes critiques of earth system governance discourse for focussing overly on existing global level governance institutions, which critical discourse has identified as part of the problem. ${ }^{39}$ Critical discourse has also appealed for inclusion of its considerations in addressing Anthropocene exigencies. ${ }^{40}$ Critical discourse furthermore points to the importance of engaging with a

34 See Biermann (2012 and 2014), above ( $\mathrm{n}_{32}$ ).

35 See the contributions in C Hamilton, C Bonneuil and F Gemenne (eds), The Anthropocene and the GlobalEnvironmental Crisis:Rethinking Modernity in a New Epoch (Routledge, 2015).

36 See, e.g., Adelman and Philippopoulos-Mihalopoulos above (n 6) and Grear above (n 14).

37 See D Chakrabarty, 'The Politics of Climate Change is More Than the Politics of Capitalism' (2017) 34(2-3) Theory, Culture \& Society 25-37.

38 A Malm and A Hornborg, 'The Geology of Mankind? A Critique of the Anthropocene Narrative' (2014) 1(1) The Anthropocene Review 62-69; E Lövbrand, S Beck, J Chilvers et al., 'Who Speaks for the Future of Earth? How Critical Social Science Can Extend the Conversation in the Anthropocene' (2015) 32 Global Environmental Change 211-218.

39 Lövbrand et al. (2015), above (n 38 ), 214.

40 Ibid. 
plurality of narratives, each with its strengths and weaknesses, enabling the re-emergence of politics in discourse. ${ }^{41}$

Legal discourse on the Anthropocene knows many voices, ranging from critical legal discourse to more classical, even if critical, legal analysis. These voices also interact. ${ }^{42}$ The focus of legal discourse is predominantly on law at the global, international or transnational levels of governance. Critical legal discourse includes illustrations of how law, and international (environmental) law in particular, serves dominant paradigms, is implicated in de-politicization and objectivation and is often neither fair nor just. ${ }^{43}$ Classical legal analysis critically illustrates how doctrines, principles and rules of international (environmental) law relate to the idea that we are living in the Anthropocene. These analyses illustrate how international (environmental) law embeds values or justice dimensions that can serve to address the idea that we are living in the Anthropocene. It further shows that the idea that we are living in the Anthropocene poses major challenges to international (environmental) law. ${ }^{44}$ The latter include the fragmented nature of international (environmental)

41 C Bonneuil, 'The Geological Turn, Narrative of the Anthropocene' in Hamilton et al., above (n 35), 17-31. Also see Lövbrand et al. (2015), above (n 38 ).

42 For a variety of insights see, Grear and Kotzé above (n 6) and Kotzé above (n 14).

43 See Grear, above (n 14); V De Lucia, 'Critical Environmental Law and the Double Register of the Anthropocene: A Biopolitical Reading' in Kotzé, above (n 14), 97-116; A Philippopoulos-Mihalopoulos, 'Critical Environmental Law in the Anthropocene', in Kotzé, above (n 14), 117-135; S Vermeylen, 'Materiality and the Ontological Turn in the Anthropocene: Establishing a Dialogue between Law, Anthropology and Eco-Philosophy', in Kotzé, above (n 14), 137-162.

44 J Verschuuren, 'The Role of Sustainable Development and the Associated Principles of Environmental Law and Governance in the Anthropocene' in Kotzé, above (n 14), 3-30; T Stephens, 'Reimagining International Environmental Law in the Anthropocene', in Kotzé, above (n 14), 31-54; BJ Richardson, 'Doing -The Temporalities of Environmental Law', in Kotzé, above (n 14), 55-74; J Ebbesson, 'Planetary Boundaries and the Matching of International Treaty Regimes', http://su.diva-portal.org/smash/get/diva2:771487/ FULLTEXTo1.pdf, originally published in (2014) 59 Scandinavian Studies in Law 261-284; $\mathrm{J}$ Ebbesson, 'Social-Ecological Security and International Law in the Anthropocene' in J Ebbesson, M Jacobsson, MA Klamberg et al. (eds), International Law and Changing Perceptions of Security (Brill, 2014) 71-92; D Vidas, 'The Earth in the Anthropocene-and the World in the Holocene?' (2015) 4(6) ESIL Reflection, https://esil-sedi.eu/post_name127/; D Vidas, J Zalsiewicz and M Williams, 'What is the Anthropocene and Why it is Relevant for International Law' (2015) 25(1) Yearbook of International Law 3-23; D Vidas, OK Fauchald, Ø Jensen and MWTvedt, 'International Law for the Anthropocene? Shifting Perspectives in Regulation of the Oceans, Environment and Genetic Resources' (2015) 9 Anthropocene 1-13. 
law ${ }^{45}$ as well as the manner in which international law relates to the divide between the global South and global North. ${ }^{46}$ Legal discourse also illustrates how international law can be rethought as the mediator of the human-environment interface through constitutionalization and human rights ${ }^{47}$ or as transnational law. ${ }^{48}$ It also includes the suggestion that ecological integrity be developed as a grundnorm for international environmental law. ${ }^{49}$ Legal discourse engages with the stratigraphic, earth system science and earth system governance discourses.

The five discourses provide rich narratives, only partially revealed in this chapter, of the idea that we are living in the Anthropocene and its implications. They do so by employing different methodologies, different ways of knowing or epistemologies. Yet the five discourses also interact, and it is through their interaction that they shape a shared conceptual space. Below I explore the nature of that space.

\section{The Space in Which Anthropocene Related Discourses Interact}

The stratigraphic and earth system science discourses, both originating in the natural sciences, clearly engage with each other. This engagement is evident from the publication of joint papers in which the insights derived from the

45 RE Kim and H van Asselt, 'Global Governance: Problem shifting in the AnthropoceneThe Limits of International Law' in E Morgera and K Kulovesi (eds), Research Handbook on International Law and Natural Resources (Edward Elgar, 2016) 473-495; SJ Turner, "The Use of "Macro" Legal Analysis in the Understanding and Development of Global Environmental Governance' (2017) 6(2) Transnational Environmental Law 237-257.

46 CG Gonzalez, 'Bridging the North-South Divide: International Environmental Law in the Anthropocene' (2015) 32 Pace Environmental Law Review 407-434; CG Gonzalez, 'Global Justice in the Anthropocene' in Kotzé, above (n 14), 219-240; see also Hey, above (n 12).

47 LJ Kotzé, 'Rethinking Global Environmental Law and Governance in the Anthropocene' (2014) 32(2) Journal of Energy \& Natural Resources Law 121-156; see also, LJ Kotzé 'Constitutional Conversations in the Anthropocene: In Search of Environmental Jus Cogens Norms' (2016) 46 Netherlands Yearbook of International Law 241-271; LJ Kotzé, 'Human Rights and the Environment in the Anthropocene' (2014) 1(3) The Anthropocene Review 252-275; LJ Kotzé, 'Global Environmental Constitutionalism in the Anthropocene' in Kotzé, above (n 14), 189-218.

48 J Lin, 'The Emergence of Transnational Environmental Law in the Anthropocene' in Kotzé, above (n 14), 329-351.

$49 \mathrm{RE}$ Kim and $\mathrm{K}$ Bosselmann, 'International Environmental Law in the Anthropocene: Towards a Purposive System of Multilateral Environmental Agreements' (2013) 2(2) Transnational Environmental Law 285-309; K Bosselmann, 'The Imperative of Ecological Integrity: Conceptualizing a Fundamental Legal Norm for a New "World System" in the Anthropocene' in Kotzé, above (n 14), 241-265. 
methodologies employed in their research are integrated. ${ }^{50}$ The relationships between these two discourses and the other three discourses seem to be of different nature. The stratigraphic and earth system science discourses hardly engage with the other three discourses, even if planetary boundaries research engages with social-ecological resilience research. Earth system governance, critical social science and legal discourses engage with the implications of the stratigraphic and earth systems science discourses mainly by exploring the implications that these have for their own discipline, that is, without necessarily coming to integrated findings. The lack of 'thick' engagement between some of the discourses can probably be explained by the difficulties involved in merging methodologies pertaining to on the one hand the natural sciences and the social sciences on the other hand. ${ }^{51}$

Interactions between the five discourses also points to contestation. Santos suggests that contestation between rival epistemologies arises in periods of paradigmatic transitions. ${ }^{52}$ I suggest that the idea that we are living in the Anthropocene can be regarded as a paradigmatic transition and that Santos' insights might be relevant for exploring the space in which Anthropocene related discourses take place.

Contestation is evidenced, for example, by how critical discourse and earth system governance discourse interact. Initially, there was limited interaction between these two discourses, but in 2016, Biermann et al. acknowledged the critique that critical discourse had voiced about earth system governance discourse. ${ }^{53}$ Biermann et al. emphasized that earth system governance discourse needs to adopt 'a cross-scalar perspective that takes into account developments at local, regional and global levels, variant connections among levels and issues domains, as well as societal inequality and injustice'.54 They also proposed a way for earth system governance research to adopt such a contextualized perspective. In particular they suggest that earth system governance needs to link in to 'a view of the planet as an interconnected, interdependent social-ecological system while taking into account both local variation and social inequalities' and applied this approach to four domains - the nitrogen cycle and food security, ocean acidification, urbanization and wildfires. ${ }^{55}$

50 See Steffen et al. above (n 11); see also, J Zalasiewicz, W Steffen, R Leinfelder et al., 'Petrifying Earth Process: The Strategic Imprint of Key Earth Systems Parameters in the Anthropocene' (2017) 24(2-3) Geosocial Formations and the Anthropocene 83-104.

$5^{1}$ Also see Brondizio et al., above (n 2 ).

$5^{2}$ See Santos, above (n 6).

53 Biermann et al. (2012), above (n 31$)$.

54 Ibid 342 .

55 Ibid. 
Biermann et al. also linked into earth system science discourse by including insights from social-ecological resilience, a concept introduced to earth system science by way of planetary boundaries research and now a prominent aspect of Future Earth. ${ }^{56}$ However, Biermann et al. do not explicitly engage with the critique raised by, for example, Lövbrand et al. who argue that the 'fundamental challenges to societal organizations posed by the Anthropocene are, paradoxically, to be countered by many of the same institutions that have allowed the recent human conquest of the natural world. ${ }^{57}$ Might this partial interaction be grounded in different methodologies? With critical discourse employing methodologies that serve to show us what is wrong with our institutions and where we are and earth system governance employing methodologies that show us how we might move on, given where we are, even if where we are is not necessarily a beautiful place.

This methodological divide does not stand on its own in Anthropocene related discourses. Biermann's 2007 suggestion to move from 'management' to 'governance' was also grounded in a methodological debate about how to ensure that the social sciences could meaningfully engage with earth system science. ${ }^{58}$ Earth system science has been keenly aware of the need to engage with the human factor since at least the late 199os. It initially engaged with the social sciences and political scientists in particular on its own terms, namely by way of modelling. ${ }^{59}$ This approach led to criticism from political scientists, some of who had been part of the IHDP also before 2009. They argued that besides statistical procedures, at the basis of modelling, additional methods are required to understand complex socio-ecological system. Such methods include meta-analyses, case studies, counterfactuals, systems analysis and simulations. ${ }^{60}$ Eventually, with the emergence of the earth system governance approach, more inclusive methods became part of the ESSP and are now part of Future Earth.

The methodological debate among Anthropocene related discourses also concerns the question who should be involved in defining the Anthropocene. ${ }^{61}$

\footnotetext{
$56 \quad$ See text above at $\mathrm{n} 21,22$ and 25 .

57 Lövbrand et al. (2015), above (n 38$), 214$.

58 Biermann (2007), above (n 28), 327-328.

59 Schellnhuber, above (n 23), for example, developed a formula for integrating the human factor into earth system science $(E=(N, H)$, where $E=E a r t h$ system; $N=$ the ecosphere and $\mathrm{H}=$ the human factor, made-up of $\mathrm{A}$ and $\mathrm{S}$, with A representing the physical effects of humans on the Earth system and $S$ the 'metaphysical' component).

6o OR Young, EF Lambin, F Alcock et al, 'A Portfolio Approach to Analyzing Complex Human-Environment Interactions: Institutions and Land Change' (2006) 11(2) Ecology and Society 31.

61 See also, Grear, above (n 14).
} 
As mentioned above, considerable debate emerged as to whether the evidence on which the Anthropocene Working Group bases its recommendation meets the standards for declaring a new geological epoch. Amid other criticisms, its work has been characterized as political rather than scientific, including by the then Chair of the International Commission on Stratigraphy. ${ }^{62}$ Members of the Anthropocene Working Group have answered this critique by emphasizing that their work is purely of a geological character and by implication part of the realm of objective knowledge. ${ }^{63}$ Yet, they also seem to be keenly aware of the political implications of their proposal that we are living in the Anthropocene, acknowledging that 'the implications of formalizing the Anthropocene reach well beyond the geological community' ${ }^{\prime}$

Erle Ellis, a member of the Anthropocene Working Group, co-authored an article suggesting that the decision on whether we are living in the Anthropocene be moved from the Working Group to a more participative, transparent and interdisciplinary body. This newly proposed body, tentatively called the 'International Anthropocene Commission' would be financed by the International Geological Congress (linked to the IUGS), Future Earth and the United Nations. ${ }^{65}$ Ellis et al. also questioned the adequacy of using the mid-twentieth century geological markers for the beginning of the Anthropocene. They suggest that these markers 'ignore[s] millennia of previous human influences', 'misrepresent the continuous nature of human changes to our planet' and 'instil a Eurocentric, elite and technocratic narrative of human engagement with our environment that is out of sync with contemporary thought in the social sciences and the humanities'.66 Ellis et al. called for the involvement of a wide array of disciplines, including those associated with critical discourse, in the decision-making process regarding the advent of the Anthropocene. Jan Zalasiewicz and Colin Waters, respectively the chairperson and the secretary of the Anthropocene Working Group, together with the chairperson of the Subcommission on Quaternary Stratigraphy reacted to this proposal by emphasizing that the work of the Anthropocene Working Group is geological in nature, focussing on whether human impact is discernible in the stratal record. ${ }^{67}$ The position taken by Zalasiewicz et al. links in to the idea that if

62 SC Finney and L Edwards, "The "Anthropocene" Epoch: Scientific Decision or Political Statement?' (2016) 26(3-4) GSA Today 4-10.

63 Zalasiewicz et al., Making the Case, above (n 17).

64 Ibid 8.

65 E Ellis, M Maslin, N Boivin and A Bauer, 'Involving Social Scientists in Defining the Anthropocene' 2016 Nature 540, 192-193.

66 Ibid 192.

67 J Zalasiewicz, C Waters and MJ Head, 'Anthropocene: Its Stratigraphic Basis' (2017) 54 Nature 289. 
the boundary between the Holocene and the Anthropocene is determined by the methodologies employed by geologists, and stratigraphers in particular, it would belong to the realm of objective knowledge. They thereby foreground objective knowledge, the classical domain of the natural sciences, as opposed to subjective knowledge, the classical domain of the social sciences. The debate between Ellis et al. and Zalasiewicz et al. illustrates engagement between the stratigraphic and critical discourses. It also illustrates that the boundary between the natural and social sciences continuous to play a significant role in the conceptual space in which Anthropocene related discourses take place.

Is this a frontier space in the conventional sense? I venture the cautious hypothesis that this space has all the multifaceted characteristics of conventional frontier space as outlined in the introduction. First, as shown above, a plurality of disciplinary discourses exists in relation to the idea that we are living in the Anthropocene. However, plurality also exists within disciplines. Second, experimentation is taking place within Anthropocene related discourses, especially in terms of seeking to understand the consequences of the Anthropocene from various disciplinary angles. More recently, experimentation is also taking place between Anthropocene related discourses by exploring the options of more integrated approaches. For example, by earth system governance integrating local and regional aspects and issues of justice and inequality, and focussing on social-ecological resilience thinking. Third, participants in the discourses seem to be keenly aware of opportunity in the sense that being part of the IGBP or IHDP and now Future Earth opens up opportunities for having ones voice heard more clearly, both because it gets one closer to decision-making forums and opens up opportunities for getting research financed. In other words, being part of Future Earth connects researchers working on the Anthropocene to the centre. Fourth, the periphery and the centre are linked, with earth system science research having longstanding and close links to the centre through its participation in the IG BP and now Future Earth. While the social sciences were first marginalized, by having to adapt to the methodologies of earth system science discourse, Frank Biermann and others paved the way for their meaningful participation in the IHDP and now in Future Earth. Critical discourse still seems to occupy a marginalized position, even if more recently it has caught the attention of both the stratigraphic and earth system governance discourses. Legal discourse interacts with and participates in all other discourses, with more classical, even if critical, legal analysis probably having closer ties to the centre than critical legal discourse. Stratigraphic discourse, because its members have strong links to earth system science discourse, is probably more closely linked to the centre than appears at first sight. 
Santos suggests that in times of paradigmatic change frontier thinking in the conventional sense is not enough. He refers to three ideal types, or topoi, of thinking that need to emerge and interact if emancipatory epistemologies are to emerge. ${ }^{68} \mathrm{He}$ refers to these ideal types as the frontier, the baroque and the South. Taking cues from Santos, I propose that the frontier mode of thinking suggests frontier space in the conventional sense, ${ }^{69}$ the baroque is a space characterized by diversity in which experimentation, and thinking the unthinkable is possible but where there is some awareness of track dependency; the South a space that points to the inequities of currently dominant institutions and that opens the possibility of solidarity and emancipation. Santos suggests that each way of thinking on its own harbours the risk of hegemony and that interaction between the three ways of thinking is crucial if eccentric, or particularist, regulation is to be avoided. ${ }^{70}$ Does the space in which Anthropocene discourses take place harbour any of these characteristics? I suggest, heuristically, that the stratigraphic, earth system science and earth system governance discourses might qualify as Santos' ideal type for frontier thinking, even if they might be getting too close to the centre to continue to qualify as frontier thinking in future. Critical discourse I suggest comes closest to what Santos refers to as the South. Legal discourse, depending on its content, can be associated with the South - critical legal discourse - or the frontier - critically exploring the boundaries of the legal discipline. I doubt if baroque discourse exists in the space in which Anthropocene related discourses take place. For baroque thinking to emerge, might we need to increase methodological interaction among the various discourses in order to move from being pioneers mainly in our own discipline to being pioneers beyond the boundaries of our disciplines? ${ }^{71}$ Might this interaction be developing in the emerging but tough practices of 'knowledge integration' and 'science with society or participatory research, ${ }^{72}$ practices which are part of Future Earth?

68 Santos, above (n 6).

69 See text above at $n$ 3-5.

70 Santos, above (n 6), 581 .

71 See also, Brondizio et al., above (n 2); N Castree, “The Anthropocene and the Environmental Humanities: Extending the Conversation' (2014) 5 (1) Environmental Humanities 233-26o.

72 LM Turner, R Bhatta, L Eriander et al., 'Transporting Ideas Between Marine and Social Sciences: Experience from Interdisciplinary Research Programs' (2017) 5 Elementa Science for the Anthropocene 14; R Seidl, FS Brand, M Stauffacher et al., 'Science with Society in the Anthropocene' (2013) 42(1) Ambio 5-12; CJ Kirchhoff, M Carmen Lemos and S Dessai, 'Actionable Knowledge for Environmental Decision Making: Broadening the Usability of Climate Science' (2013) 38 Annual Review of Environment and Resources 393-414; M Faling, J Garard, G Schouten et al., 'Innovative Participatory Research Methods in Earth System Governance' (2017) 12 Annual Review of Social Partnerships 76-80. 
Future Earth focusses on integrating distinct ways of knowing that characterize different disciplines as well as participatory research, however, it also harbours a certain path dependence. The latter is evidenced by its Global Research Projects, most of which were also part of the ESSP or linked to the IGBP or the IHDP. ${ }^{73}$ Yet, many of these projects now include a wider variety of disciplines and engage in participatory research.${ }^{74}$ Future Earth also includes Knowledge Action Networks, which 'involve fundamental research, integration of natural and social sciences and humanities, co-designed research questions with users, co-produced outcomes, and broader engagement activities through state-of-the-art communications, dialogues and involvement at policy interfaces' ${ }^{75}$ While it is too early to assess the outcomes of these networks, they might well evolve as stimulators of change, perhaps leading to what Santos refers to as baroque ways of thinking, also influencing the Global Research Projects.

How interactions among disciplinary discourses might evolve and whether there is sufficient interaction to avoid hegemony and eccentric regulation might not materialize first in decision-making regarding the definition of the Anthropocene. As mentioned above, it may take a while for that decision to emerge, irrespective of whether it takes place in the IUGS or in the proposed International Anthropocene Commission. Instead, how various Anthropocene related discourses interact might emerge sooner in the context of, for example, geoengineering, which is moving to an experimental stage. ${ }^{76}$ Geoengineering

73 See Future Earth, 'Our History', https://futureearth.org/about/history/; see also, Castree, above (n 71).

74 For a critical assessment see S van der Hel, 'New Science for Global Sustainability? The Institutionalisation of Knowledge Co-production in Future Earth' (2016) 61 Environmental Science \& Policy $165^{-175}$.

75 See Future Earth, 'Knowledge-Action Networks', https://futureearth.org/networks/ knowledge-action-networks/.

76 See, e.g., J Temple, 'Harvard Scientists Moving Ahead on Plans for Atmospheric Geoengineering Experiments' MIT Technology Review (24 March 2017), https://www. technologyreview.com/s/6o3974/harvard-scientists-moving-ahead-on-plans-foratmospheric-geoengineering-experiments/; see also, S DeWeerdt, 'While We Debate Geoengineering the Ocean, It Seems We're Already Doing It' Daily Science (6 August 2019), http://www.anthropocenemagazine.org/2019/o8/while-we-debate-geoengineering-theocean-it-seems-were-already-doing-it/. 
has been part of earth system science discourse, even if addressed cautiously. For example, Paul Crutzen, in a 2006 editorial essay, discussed the option of releasing sulphur into the stratosphere in order to enhance its capacity to reflect sunlight and thus help cool the Earth, a form of geoengineering. The essay ends with the following statement, '[F]inally, I repeat: the very best would be if emissions of the greenhouse gases could be reduced so much that the stratospheric sulfur release experiment would not need to take place., ${ }^{77}$ Despite this statement, critical discourse has critiqued Crutzen's position for being too open to the option of geoengineering. ${ }^{78}$ Legal discourse has explored the potentialities of and challenges faced by international law if it is to address geoengineering. ${ }^{79}$ Earth system governance discourse has suggested that, whether we like it or not, we need to engage with the topic. ${ }^{80}$ How might these discourses interact? Knowledge integration and participatory research may offer ways forward. ${ }^{81}$

I also suggest that in order to enable a thick sharing of the conceptual space in which Anthropocene related discourses interact we need to take Brunno Latour's insight seriously. ${ }^{82}$ Namely, that the distinction between understandings of interactions in nature and in society - between objective and subjective knowledge - is a misunderstanding of the insights that the natural and social sciences generate. This insight should make us understand that findings regarding the advent of the Anthropocene, emanating from geology, are not mere facts out there but the result of human mediation and that such findings are often loaded with normative implications. One might remember Latour's reference to the statement 'there is a cat in a basket on the seat' directed at a rather corpulent and distracted man who is about to sit on the seat. ${ }^{83}$ When we state that the Earth system is or there are planetary

77 P Crutzen, 'Albedo Enhancement by Stratospheric Sulfur Injections: A Contribution to Resolve a Policy Dilemma?' (2006) 77 Climate Change 211-210.

78 Lövbrand et al. (2009), above (n 23), 11.

79 KN Scott, 'International Law in the Anthropocene; Responding to the Geoengineering Challenge' (2013) 34(2) Michigan Journal of International Law 309-358; KN Scott, 'Engineering the "Mis-Anthropocene": International Law, Ethics and Geoengineering' (2015) 29 Ocean Yearbook 61-84.

8o Biermann (2012), above (n 32), 8 .

81 V Galaz, 'Geo-engineering, Governance, and Social-ecological Systems: Critical Issues and Joint Research Needs' (2010) 17(1) Ecology and Society 24; M Sugiyama, Y Arino, T Kosugi et al., 'Next Steps in Geoengineering Scenario Research: Limited Deployment Scenarios and Beyond' (2018) 18(6) Climate Policy 681-689.

82 Latour, above (n 13$)$.

83 Ibid 58 . 
boundaries, social-ecological systems or human rights 'on the seat' - which by implication will be 'sat on', unless we adjust our behaviour - we are issuing a statement with normative, or performative, implications. Such statements are mediated by, dare I say, our expertise in the conceptual frontier space in which Anthropocene discourses are taking place. 